\title{
THE INTERACTION BETWEEN AN ENTREPRENEURIAL MARKETING ORIENTATION AND COOPETITION ON BUSINESS PERFORMANCE
}

\begin{abstract}
Purpose - Certain small businesses do not possess the assets needed to implement a performance-enhancing entrepreneurial marketing orientation (opportunity-driven behaviours focused on creating value for customers). Although some entrepreneurs cooperate with their competitors (coopetition) to achieve their day-to-day and long-term goals, it is unclear whether these partnerships are advantageous in this capacity. Thus, grounded in the resource-based view, the purpose of this investigation is to examine whether coopetition positively moderates the relationship between an entrepreneurial marketing orientation and financial performance.
\end{abstract}

Design/methodology/approach - Survey responses were obtained from 184 small tourism and hospitality organisations in New Zealand. Following a series of robustness checks, covariance-based structural equation modelling was used to test the elements of the conceptual model.

Findings - Unique insights illustrate an entrepreneurial marketing orientation yielding a negative and significant link with financial performance. Nevertheless, this result was potentially related to the entrepreneurial marketingoriented opportunities that owner-managers pursued within the context of their sector. Not least, where employing an individualistic business model constrained certain decision-makers' ability to pursue 'growthoriented' objectives. However, coopetition produced a positive and significant moderating effect, enabling ownermanagers to pursue opportunities via collaborative business models facilitating mutually beneficial performance outcomes.

Practical implications - Owner-managers of under-resourced small firms should be careful when implementing entrepreneurial marketing strategies utilising an individualistic business model. For example, they might pursue opportunities that are not viable and/or become over-loaded with market intelligence that they cannot handle. By collaborating with competitors, owner-managers can learn improved ways to operate within their industries, alongside being equipped with new resources and capabilities. In doing so, coopetition can help overcome some of the potential performance-limiting issues owner-managers face by being under-resourced, namely, via employing a collaborative business model.

Originality/value - This current study contributes to the extant literature by evaluating the complexities of entrepreneurial marketing practices. That is, although earlier research has focused on the performance-driving outcomes of an entrepreneurial marketing orientation, prior studies typically overlook certain moderating factors that could influence this association. By examining the interaction between an entrepreneurial marketing orientation and coopetition on financial performance, new evidence has emerged on how owner-managers of small firms can utilise inter-firm cooperation to succeed within their markets, as opposed to struggling to cope with the challenges of an individualistic business model. Specifically, an entrepreneurial marketing orientation is likely to enhance financial performance when under-resourced companies effectively collaborate with their competitors.

Keywords - Coopetition; entrepreneurial marketing orientation; financial performance; resource-based view; small companies.

Classification - Research paper. 


\section{Introduction}

"Entrepreneurial marketing is not only limited to business-to-consumer firms, but also includes business-tobusiness organisations that need entrepreneurial marketing in order to create value through networks and innovation" (Alqahtani and Uslay, 2020, p. 63).

Decision-makers often face the challenge of adding value to customers within their evolving business models (Osterwalder and Pigneur, 2010; Gassmann et al., 2014). To help small firms to cope with the pressures of operating within changing environmental conditions, there has been a growing body of knowledge surrounding the merits of owner-managers possessing an entrepreneurial marketing orientation (Morris et al., 2002; Hills et al., 2008; Hansen and Eggers, 2010; Morrish et al., 2010; Hansen et al., 2020). This construct (sometimes termed the marketing/entrepreneurship interface) was recently defined as "an agile mind-set that pragmatically leverages resources, employs networks, and takes acceptable risks to proactively exploit opportunities for innovation co-creation, and delivery of value to stakeholders, including customers, employees, and platform allies" (Alqahtani and Uslay, 2020, p. 64).

A recognition exists that entrepreneurial marketing behaviours are intended to yield higher-levels of company performance through implementing the advantages of market-oriented and entrepreneurially-oriented strategies (Jones and Rowley, 2011; Boso et al., 2013). However, earlier literature suggests performance from an entrepreneurial marketing perspective can vary due to the pursuit of opportunities across contexts; hence, it is important and timely to unpack the nature of the entrepreneurial marketing-performance relationship. For example, Roundy (2017) noted that entrepreneurial marketing principles are applicable to firms with not-for-profit objectives despite existing studies typically focusing on profit-oriented businesses. Furthermore, Crick et al. (2018) in a UK tourism study highlighted the importance of owner-managers' objectives, with some pursuing lifestyle rather than growth objectives. Indeed, they found that owner-managers are likely to pivot their business model over time and hence a temporal dimension can affect performance outcomes. Nevertheless, while some studies have investigated the relationship between an entrepreneurial marketing orientation (or synonymous constructs) and company performance (Sadiku-Dushi et al., 2019; Eggers et al., 2020), they have largely 
overlooked the complexities of these organisation-wide behaviours, namely, the role of potential moderating factors.

Indeed, certain scholars have recognised that to increase the likelihood for entrepreneurial marketing behaviours to be successful, owner-managers often require to move from an individualistic business model and engage with key network partners to achieve their goals (Whalen et al., 2016; Crick and Crick, 2018). However, since network partners can encapsulate various stakeholders, such as customers, suppliers, public sector agencies, and rivals (Bernal et al., 2002; Dana and Winstone, 2008; Felzensztein et al., 2010; 2019; Karami and Tang, 2019), there is a lack of clarity regarding the role of particular actors that can strengthen the performance outcomes of an entrepreneurial marketing orientation. This current study focuses on 'coopetition', namely, "a paradoxical relationship between two or more actors, regardless of whether they are involved in horizontal or vertical relationships, simultaneously in cooperative and competitive interactions" (Bengtsson and Kock, 2014, p. 180). Nevertheless, despite a coopetition strategy being perceived as 'paradoxical' from a marketing perspective (as per Bengtsson and Kock, 2014), from an entrepreneurial perspective it appears seemingly rational (Kraus et al., 2019; Crick and Crick, 2020). Specifically, for under-resourced firms, it provides a potential mutually beneficial performance-enhancing strategy by pooling certain resources/capabilities to pursue opportunities more difficult by employing an individualistic business model; that is, assuming potential tensions are minimised (Dana et al., 2013; Bengtsson and Johansson, 2014; Raza-Ullah et al., 2014; Granata et al., 2018; Crick, 2020).

Drawing upon resource-based theory (Barney, 1991; 2001; 2018), the objective is to investigate whether coopetition positively moderates the relationship between an entrepreneurial marketing orientation and financial performance ${ }^{1}$. This investigation provides three contributions to the extant literature:

\footnotetext{
${ }^{1}$ While coopetition is a business-to-business strategy, it has applications to the business-to-consumer domain. For example, a firm might share assets with rivals to enhance performance opportunities, but sell via intermediaries like distributors or direct to consumers (Crick and Crick, 2020). By exploring coopetition as a potential moderator in the link between an entrepreneurial marketing orientation and financial performance, integration takes place of these aspects of the cross-disciplinary literature.
} 
1. Drawing on recent trends in the broader entrepreneurship literature and more specifically coopetition research (Bouncken et al., 2015; Ferreira et al., 2019), stronger insights emerge regarding the relationship between an entrepreneurial marketing orientation and financial performance. Specifically, demonstrating that employing such an orientation is not always performance-enhancing (extending Sadiku-Dushi et al., 2019; Eggers et al., 2020).

2. The networking themes of the resource-based view are developed and rather than concentrating on the seminal inside-the-firm issues that affect competitive rivalry, appreciation of an outside-in perspective features the role of coopetition as a performance-enhancing strategy (building on Day, 2014; Mu et al., 2018; Rust, 2020).

3. Context features as an important consideration in firms' entrepreneurial marketing activities (as per Jones and Rowley, 2011). Specifically, whereby business-to-business practices among firms within the hospitality and tourism sector can enhance the performance consequences of engaging in business-toconsumer activities (extending Czakon and Czernek, 2016; Czernek et al., 2017; Crick et al., 2018). However, simply possession of resources/capabilities may be insufficient and strategic flexibility is important (as per Priem and Butler, 2001).

To make these three contributions, the subsequent five sections outline the facets of this study. First, consideration takes place of resource-based theory as the underpinning lens, followed by the development of the conceptual model positioned within the entrepreneurial marketing domain. Second, the research design is described. Third, the results are shown. Fourth, these findings are related to the extant literature. Fifth, the investigation ends with several managerial recommendations and recognition of some limitations together with avenues for future research.

\section{Theoretical background and hypothesis development}

The foundations of resource-based theory

The resource-based view examines the ways that organisations utilise their resources and capabilities to enhance performance; whereby, resources refer to tangible assets, such as financial capital and technological 
hardware, whereas, capabilities are intangible and include knowledge together with experience (Hunt and Morgan, 1995; Lavie, 2006; Kellermanns et al., 2016; Nason and Wiklund, 2018). A core element of this perspective is the value, rarity, inimitability, and non-substitutability (VRIN) framework, which is used to assess how businesses can leverage their resources and capabilities to out-perform their rivals (Barney, 1991). In fact, this viewpoint includes various measures of performance, with some companies (small and large) using financial metrics, such as sales and profitability (Ray et al., 2004; Morgan et al., 2009; Vorhies et al., 2011). Therefore, in this current study, financial performance served as the outcome variable.

Key changes made to the resource-based view

Driven by the VRIN framework, the resource-based view has traditionally been considered from an inside-thefirm perspective (Barney, 1991; Hunt and Morgan, 1995). However, this perspective has evolved by offering new ways that organisations can survive and grow within their markets. As an example, Barney (2001) and Priem and Butler (2001) noted a range of under-represented areas from this perspective and how academics can overcome them. For instance, they highlighted that despite it being an external factor, the competitive business environment can affect the extent to which organisational resources and capabilities drive firm-level success. As such, conceptualisations and empirical findings have explored how environmental contingencies (like market turbulence) can moderate the link between certain strategies and performance (Cadogan et al., 2009; Sundqvist et al., 2012). Likewise, Barney (2001) and Priem and Butler (2001) recommended that the resource-based view should consider not simply possession of resources/capabilities, but rather "strategic flexibility" in respect of decision-makers' ability to pivot their business models within volatile markets. Indeed, Hughes et al. (2020) offer a readiness index for owner-managers to survive or even thrive in the light of environmental circumstances. In this current study, these extensions are considered by exploring how owner-managers engage in coopetition activities to strengthen their performance-enhancing entrepreneurial marketing behaviours.

More recently, an 'outside-in' perspective has gained a degree of prominence in contrast to the inside-the-firm perspective of Barney (1991). Specifically, the extent that decision-makers are market-led (see Day, 2014; Mu et al., 2018; Rust, 2020); for example, Day (2014, p.28) poses certain potential questions. "How and why are 
customers changing? What new needs do they have? What can we do to solve their problems and help them make more money? What new competitors are lurking around the corner, and how can we derail their efforts?" Coopetition nonetheless offers an opportunity to collaborate with, as opposed to trying to derail a competitor (following Day, 2014), including: the pooling of funds, sharing equipment and knowledge, plus cooperative innovation practices (Bouncken and Krauss, 2013; Bouncken et al., 2018; Crick and Crick, 2020).

Consequently, while resource-based theory helps explain how assets can be leveraged to boost performance, it often overlooks how certain businesses work with key stakeholders (including competitors) in their day-to-day and long-term activities (Crick and Crick, 2021). Therefore, Hunt and Derozier (2004) suggest that the resourcebased view should cover key relational factors that surround cooperative activities. More recently, Barney (2018) offered a related suggestion, whereby, resource-based theory should incorporate a stakeholder dimension. These extensions encapsulate the seminal elements of the lens (as per the VRIN framework) that were competitive in nature (Barney, 2001; Priem and Butler, 2001), alongside such networking themes. Accordingly, this current study builds upon these issues by investigating whether coopetition positively moderates the entrepreneurial marketing orientation - financial performance relationship.

\section{The Entrepreneurial Marketing Domain}

Academic interest has gained prominence in the entrepreneurial marketing domain (Hills and La Forge, 1992, Hills and Hultman, 2011; Thomas et al., 2013; Miles et al., 2015; Morrish et al., 2020). There have been different conceptualisations and measures of entrepreneurial marketing activities. One common viewpoint is that this is comprised of seven dimensions, namely, proactiveness, risk-taking, innovativeness, opportunity focus, resource leveraging, customer intensity, and value creation activities (Morris et al., 2002). Another school-of-thought is that it exists at the intersection between a market orientation and an entrepreneurial orientation (Jones and Rowley, 2011; Hansen et al., 2020). Consequently, this current study builds upon this latter way of thinking by conceptualising (and later operationalising) an entrepreneurial marketing orientation as encapsulating the combination of market-oriented and entrepreneurially-oriented activities (following Baker and Sinkula, 2009; Morgan et al., 2015). It builds upon earlier work that has highlighted the performance-enhancing benefits of an 
entrepreneurial marketing orientation (Sadiku-Dushi et al., 2019; Eggers et al., 2020), with stronger evidence regarding how coopetition (as a fundamental business-to-business strategy) can help small under-resourced firms to achieve their day-to-day and long-term goals. In doing so, the networking themes of entrepreneurial marketing behaviour are developed (extending Whalen et al., 2016).

\section{Conceptual model}

Underpinned by the resource-based view (Barney, 1991; 2001; 2018), the study's conceptual model (Figure 1) contained two hypothesised paths and eleven control variables. First, an entrepreneurial marketing orientation was expected to enhance financial performance (Jones and Rowley, 2011; Hansen et al., 2020). Second, given the importance of network relationships (Whalen et al., 2016; Alqahtani and Uslay, 2020), coopetition was anticipated to positively moderate the link between an entrepreneurial marketing orientation and financial performance. Third, the outcome variable (financial performance) was controlled for firm size, firm age, degree of internationalisation, the facets of a market orientation (intelligence generation, intelligence dissemination, and intelligence responsiveness), and the dimensions of an entrepreneurial orientation (innovativeness, proactiveness, risk-taking, autonomy, and competitive aggressiveness). Together, earlier studies have illustrated the potential influence of these issues as described later (Jaworski and Kohli, 1993; Morgan et al., 2009; Vorhies et al., 2011; Crick and Crick, 2016a; Karami and Tang, 2019; Wales et al., 2021).

\section{[Insert Figure 1 about here]}

\section{An entrepreneurial marketing orientation and financial performance}

As already noted, an entrepreneurial marketing orientation encompasses the forces of a market orientation and an entrepreneurial orientation (Baker and Sinkula, 2009; Morgan et al., 2015). Market-oriented behaviours involve the generation of, dissemination of, and responsiveness to market intelligence, which in turn, contribute to the organisation-wide implementation of the marketing concept (Cadogan et al., 2009). There are different conceptualisations and operationalisations of the market orientation construct (like Kohli and Jaworski, 1990; Narver and Slater, 1990), but these perspectives are linked by the common theme of being a set of firm-wide information-processing activities regarding customers and competitors (Cadogan and Diamantopoulos, 1995). 
Linking with the resource-based view, a market orientation features under the VRIN framework, whereby, it can be leveraged as a set of resources and capabilities that serve the purpose of satisfying the wants and needs of customers (as per Hunt and Morgan, 1995). This helps explain why existing research has uncovered that a market orientation is likely to lead to higher-levels of company performance if implemented effectively (Slater and Narver, 1994; Hodgkinson et al., 2012; Powers et al., 2020). This can be attributed to a market orientation helping decision-makers to acquire information about mechanisms to satisfy their customers' wants and needs; also, staying ahead of competitors (Hult and Ketchen Jr., 2001).

Consistent with a market orientation, the entrepreneurial orientation construct has been conceptualised and measured in various ways (Wiklund and Shepherd, 2005; Wales et al., 2013; Adomako et al., 2016; Morgan et al., 2016). It has been classified as a five-component variable, comprised of innovative, proactive, risk-taking, autonomous, and competitively aggressive behaviours (Boso et al., 2013). If employed effectively, such behaviour can help small businesses to navigate the pressures of rivalrous markets to achieve their short-term and long-term goals (Covin and Slevin, 1989). That is, smaller-sized firms can be creative, forward-looking, and pursue risky product-markets - that could yield larger pay-offs if they are successful (Lumpkin and Dess, 1996). Further, entrepreneurially-oriented behaviours could encourage owner-managers to experiment with innovative practices to develop superior goods and services in ways that their key competitors cannot imitate (Morgan et al., 2015).

Strategies in pursuit of opportunities are likely aligned to owner-managers' objectives that may not necessarily be growth-oriented (Crick et al., 2018). Nevertheless, since an entrepreneurial marketing orientation exists at the intersection between a market orientation and an entrepreneurial orientation, it makes sense that these strategies are advantageous for owner-managers to implement (Hansen et al., 2020). Put simply, "firms that excel in employing networks, paying inclusive attention, fostering innovation, leveraging resources, taking acceptable risks, co-creating value, embracing proactiveness, and being opportunity-focused will tend to have a better overall performance" (Alqahtani and Uslay, 2020, p. 66). Furthermore, an entrepreneurial marketing orientation helps owner-managers to create day-to-day and long-term processes that focus on creating value 
for customers, alongside being opportunity-driven to achieve such goals (Hultman and Hills, 2011; Jones and Rowley, 2011). This includes developing a company-wide mind-set that is committed to being opportunity-driven, so that members of staff can play some part in satisfying their customers' wants and needs (Morrish et al., 2010). By managing these behaviours, owner-managers of under-resourced small businesses should be more successful than those that do not foster an entrepreneurial marketing orientation (Eggers et al., 2020). Therefore, it expected that:

H1. An entrepreneurial marketing orientation is positively related to financial performance.

The moderating role of coopetition

Consideration of the notion of coopetition has taken place in particular ways, such as being an organisationwide mind-set through to manifesting via a collection of organisation-wide behaviours (Bengtsson and Kock, 2014; Bouncken et al., 2020; Crick and Crick, 2020). Linking with the resource-based view, behavioural forms of coopetition help under-resourced companies to access new assets and opportunities that would be more difficult to acquire if they operated without help from their rivals (Ritala, 2012; Velu, 2016). As an illustration, Crick and Crick (2020) found via secondary sources that various businesses (small and large) have been collaborating with their competitors in response to the COVID-19 pandemic and exhibiting strategic flexibility by pivoting their business models. They noted that coopetition strategies assist these firms to survive and grow within their markets due to being equipped with the appropriate assets that might be the difference between surviving and failing in these turbulent climates. However, risk/reward considerations exist in choosing coopetition partners (Chiambaretto et al., 2020), since not all rivals are the same (Yan et al., 2020).

Turning to an entrepreneurial marketing orientation, if decision-makers collaborate with trustworthy and complementary competitors, this form of networking leverages resources/capabilities and is likely to assist them to achieve their objectives (Hannah and Eisenhardt, 2018; Hoffmann et al., 2018; Czakon et al., 2020; Estrada and Dong, 2020). Put another way, "coopetition is linked with the entrepreneurial marketing literature, as it involves companies taking bold steps (proactive), creative activities (innovative), and making potentially risky decisions (risk-taking), involving the interplay between cooperation and competition, which could yield 
improvements in organisational performance, such as sales" (Crick and Crick, 2019, p. 668). In doing so, small companies can sometimes acquire information and equipment from their rivals (that in certain cases might be easy to reach due to existing social capital2 ${ }^{2}$, as well as geographic factors) to improve their market-level success (Geldes et al., 2017; Crick, 2015).

It could be that decision-makers possess appropriate ideas to operate their ventures, but do not have the sufficient quantity of resources and capabilities to achieve such short-term and long-term goals (Morrish et al., 2010). Instead of coping with the challenges (and potential dangers) of an individualistic business model, coopetition can lessen these risks by assisting small companies to acquire new assets that can allow strategies to manifest into higher-levels of financial performance (Bengtsson and Kock, 2014). That is, as opposed to other types of stakeholders having different forms of expertise such as business advisors, investors and government support providers (Crick, 1992; Crick and Chaudhry, 2000; Crick and Crick, 2018). Nonetheless, with resourcedisadvantages, owner-managers must carefully invest their time, so that they maximise the value of their partnerships. Hence, assuming a level of trust exists and relationships are effectively managed (Raza-Ullah et al., 2014; Tidstrom, 2014; Bengtsson et al., 2016), coopetition is proposed to serve as an effective form of networking to increase the performance outcomes of an entrepreneurial marketing orientation. Accordingly, it follows that:

H2. Coopetition positively moderates the link between an entrepreneurial marketing orientation and financial performance.

\section{Control variables}

Grounded in the resource-based view (Barney, 1991), financial performance was controlled for the following constructs. First, concerning firm size, larger businesses normally possess a greater quantity of resources and capabilities that can allow them to out-perform smaller players in their sectors (Morgan et al., 2009). Second, regarding firm age, older companies might have acquired performance-enhancing information about their

2 Social capital's importance among decision-makers within a relatively close proximity is observed across sectors like accommodation (Crick and Crick, 2016b), restaurants (Chaudhry and Crick, 2004; Crick et al., 2016) and firms with diversified business models like vineyards having cafes, restaurants, etc. (Crick and Crick, 2015). 
customers and competitors through trading over an extended period compared to younger organisations (Vorhies et al., 2011). Third, in terms of degree of internationalisation, businesses that have customers from outside of their home countries have increased scope to access new opportunities and hence policy makers offer various assistance to support overseas activities (Bell et al., 1998; Chaudhry and Crick, 1998; Kahiya et al., 2014). In fact, Kahiya (2020) notes the limited domestic market for certain small countries like New Zealand that features in this current study whereby international customers are often important for scalability among owner-managers with growth-oriented objectives. Fourth, turning to a market orientation, by obtaining and acting upon market intelligence, decision-makers can adapt their strategies to develop a superior customer value proposition compared to their rivals (Jaworski and Kohli, 1993). Fifth, an entrepreneurial orientation helps ownermanagers to be innovative and proactive, take calculated risks, be autonomous, and exhibit competitively aggressive actions to achieve their objectives (Wiklund and Shepherd, 2005). The methodology employed in this current study is described in the next section.

\section{Methods}

Population of interest

The authors focused on small tourism and hospitality operators in New Zealand, whereby $97 \%$ of firms in New Zealand are small businesses which account for $28 \%$ of employment and over a quarter of the country's gross domestic product (GDP) (MBIE, 2020). Tourism contributes over 20\% to New Zealand's total exports (Tourism New Zealand, 2020), contributing 6.1 percent to New Zealand's economy (NZTE, 2020), and accounts for 8.4 percent of the total number of people employed in New Zealand (Tourism New Zealand, 2020). Regarding an entrepreneurial marketing orientation, earlier studies suggest firms in the sector (across several countries) are often opportunity-driven and committed to creating a positive experience for their customers (Moriarty et al., 2008; Crick et al., 2018). In terms of networking and coopetition more specifically, firms (from around the world) with aspects of their business models associated with tourism and hospitality frequently collaborate (Czakon and Czernek, 2016; Czernek et al., 2017; Crick et al., 2018); not least, to promote their regional clusters, with the objective being to attract new and returning visitors. In the context of this current study, New Zealand is one 
of the more popular tourism and hospitality destinations in the world, with its positive reputation for supplying these offerings (Vasta, 2020). The key informants were the owner-managers of these businesses, having authority in decision-making needed to engage in coopetition and assess performance outcomes (see Crick and Crick, 2018); also, an entrepreneurial marketing orientation often being fostered by these individuals (SadikuDushi et al., 2019).

\section{Data collection}

The research team designed an electronic survey (through Qualtrics) that included operationalisations of the latent variables. Next, the survey was pre-tested with a sample of scholars $(n=8)$ and practitioners $(n=5)$, who could offer feedback on its content (Reynolds and Diamantopoulos, 1998). No problems were encountered during the pre-testing process. Afterwards, the researchers engaged a reputable market research agency in 2020 with sampling key decision-makers within small tourism and hospitality firms from the chosen population of interest (following Hagtvedt, 2011). They were instructed to collect credible data, such as there being no missing responses and the participants not rushing through the questions. A pilot study was launched $(n=50)$, which involved checking the descriptive statistics, revealing no concerns (Hunt et al., 1982). Lastly, the core study was implemented $(n=134)$. Since no adaptations were made after the pilot study, the two datasets were merged (as per Morgan and Hunt, 1994). Thus, the final sample size was 184 (50 plus 134) observations. While the response rate could not be calculated (owing to the role of the market research agency), this sample size was sufficient to undertake the statistical tests and passed robustness checks discussed shortly.

\section{Measurement scales}

The constructs were operationalised as follows ${ }^{3}$. First, the facets of a market orientation were measured using Jaworski and Kohli's (1993) MARKOR scale, namely, intelligence generation (four items), intelligence

\footnotetext{
3 For statistical purposes, the constructs were - intelligence generation (GN), intelligence dissemination (DS), intelligence responsiveness (RP), innovativeness (IN), proactiveness (PT), risk-taking (RK), autonomy (AO), competitive aggressiveness (CA), an entrepreneurial marketing orientation (EMO), coopetition (CO), financial performance (PF), informant quality (IQ), firm size (SZ), firm age (AGE), and degree of internationalisation (IT). Furthermore, industry experience (the instrumental variable) was denoted as EN.
} 
dissemination (five items), and intelligence responsiveness (five items), each using seven-point Likert scales, ranging from: 1 = very strongly disagree to $7=$ very strongly agree. The MARKOR scale was an appropriate measure because the research team were focused on behavioural forms of market orientation. This meant that Narver and Slater's (1990) MKTOR scale (or other instruments), which applies to corporate cultures, was less suitable. Second, the dimensions of an entrepreneurial orientation, namely, innovativeness (five items), proactiveness (three items), risk-taking (three items), autonomy (three items), and competitive aggressiveness (three items) were captured using seven-point Likert scales, ranging from: $1=$ very strongly disagree to 7 = very strongly agree (adapted from Sundqvist et al., 2012; Boso et al., 2013). Third, an entrepreneurial marketing orientation was operationalised as a composite interaction between the components of the refined market orientation and entrepreneurial orientation scales (following Baker and Sinkula, 2009; Morgan et al., 2015). Fourth, financial performance was captured on a seven-point interval scale, with five items, ranging from: $1=$ much worse than competitors to 7 = much better than competitors (adapted from Morgan et al., 2009).

Fifth, coopetition was measured using a seven-point Likert scale, with five items, ranging from: $1=$ very strongly disagree to 7 = very strongly agree (adapted from Bouncken and Kraus, 2013; Bouncken et al., 2018). Although there are various measures of the coopetition construct, an appropriate tool is one that captures the propensity of these strategies (see Crick and Crick, 2021). As such, the chosen scale served this purpose. Sixth, firm size was measured through the number of employees within the sampled organisations (Josephson et al., 2016). Seventh, firm age was operationalised via the number of years that these businesses had been operating (Vorhies et al., 2011). Eighth, degree of internationalisation was captured through the proportion of their annual revenues that originated from foreign customers (adapted from Liu et al., 2014). Ninth, informant quality (the marker variable) was captured using a seven-point Likert scale, with five items, ranging from: $1=$ very strongly disagree to 7 = very strongly agree (adapted from Hultman et al., 2009). Tenth, industry experience (the instrumental variable) was measured through the number of years that the key informants had been working in the global tourism and hospitality sector (Chi and Gursoy, 2009). As a final measurement issue, natural logarithms were used to reduce the variance of the single-indicators. 


\section{Data analysis}

The survey data were analysed using the following techniques. First, through SPSS 24, the characteristics of the final sample were investigated (Churchill Jr., 1979). Various smaller-sized tourism and hospitality companies participated in this investigation, being located throughout New Zealand (Table 1).

\section{[Insert Table 1 about here]}

Second, via SPSS 24, an exploratory factor analysis model was conducted, with a principal components analysis extraction and a varimax rotation (Peterson, 2000). Several items were removed because they created crossfactor loadings. After these items were deleted, the items for the multi-item scales loaded onto eleven factors (Table 2). The underlying factor structure of the measurement scales was not distorted by this aspect of the scale purification process (as per Crick, 2021). The Kaiser-Meyer-Olkin (KMO) test of sampling adequacy (0.86) and Bartlett's test of sphericity $\left(X^{2}=5,155.06 ; d f=780 ;\right.$ Sig. $\left.=0.00\right)$, produced satisfactory results (explaining $77.01 \%$ of the total variance).

\section{[Insert Table 2 about here]}

Third, using LISREL 8.71 a confirmatory factor analysis was employed (Souchon et al., 2016). A few indicators were removed, as they negatively impacted the measurement model. The final (purified) multi-item scales were satisfactory (Table 3). The model fit indices met the minimum thresholds $\left(X^{2}=651.90 ; d f=427 ; X^{2} / d f=1.53\right.$; Sig. = 0.00; RMSEA = 0.05; CFI = 0.96; IFI = 0.97; NNFI = 0.95; SRMR = 0.05).

\section{[Insert Table 3 about here]}

Fourth, using LISREL 8.71, the elements of the conceptual framework were tested through covariance-based structural equation modelling (Sundqvist et al., 2012). During this process, the research team recorded the unstandardised path estimates $(\mathrm{V})$ and their t-values. Additionally, the structural model fit indices were checked, together with the squared multiple correlation (Boso et al., 2013). Then, "residual-centering" was used to test the interaction effect, as a step towards alleviating multi-collinearity errors (Crick, 2021). Further, paths were 
evaluated once all independent variables were "nested" within the analysis (Cadogan et al., 2009). The final sample was large enough to employ covariance-based structural equation modelling ${ }^{4}$ (see Moorman, 1995).

\section{Reliability and validity}

Regarding reliability, the multi-item scales were checked for internal consistency (Churchill Jr., 1979). Face validity was addressed by pre-testing the survey with a selection of expert scholars and practitioners (Reynolds and Diamantopoulos, 1998), alongside utilising an informant quality scale (adapted from Hultman et al., 2009). Content validity was assured by using established measures (Peter, 1981). Convergent validity existed through the composite reliabilities and the average variance extracted values exceeding the minimum benchmarks (Souchon et al., 2016). Discriminant validity was tested by comparing the squared phi matrix correlations (accessed via LISREL 8.71) against the average variance extracted values. Since the largest squared phi matrix correlation (0.38) was less than the smallest average variance extracted $(0.56)$, the check for discriminant validity met the expected threshold (Fornell and Larcker, 1981).

\section{Common method variance}

Various procedural and statistical techniques exist that can be used to address common method variance. In this current study, the survey was as short and engaging as possible to reduce respondent fatigue (Podsakoff et al., 2003). Moreover, the market research agency was tasked to ensure that the key informants completed the survey in a reasonable amount of time by not rushing through questions (following Hagtvedt, 2011). Afterwards, the marker variable technique was utilised (via SPSS 24). This involved producing a bivariate correlation matrix that contained the latent variables featured in the testing of the research hypotheses and control paths. Then, a partial correlation matrix was created, with the same constructs, but controlling for the informant quality scale as the marker variable (adapted from Hultman et al., 2009). The differences between the

\footnotetext{
4 To supplement the covariance-based structural equation modelling stage, a "spotlight analysis" was undertaken (Irwin and McClelland, 2001). This involved using Microsoft Excel to plot the slopes of the moderator (coopetition) at one standard deviation (1.48) below and above the mean (4.10) (Guo, 2013). This test was used to unpack the interaction effect.
} 
two correlation matrices were calculated and averaged $(r=0.03)$. This signified that the data were unlikely to be influenced by a common method factor (Lindell and Whitney, 2001). Moreover, the informant quality scale had a considerably large variance (1.23), allowing it to serve as the marker variable.

\section{Endogeneity bias}

There are a number of ways to evaluate endogeneity bias. In this current investigation, the research team used LISREL 8.71 across the subsequent steps. First, the conceptual framework was refined to evaluate the coopetition - financial performance path. Second, an instrument was chosen, as a construct that is conceptually related to coopetition, but not financial performance. Industry experience served as the instrumental variable because if owner-managers possess sector-wide knowledge about their customers and competitors, they can utilise it to engage in effective coopetition strategies (Crick, 2021). Third, two structural models were produced, one depicting the association between coopetition and financial performance and another that included the instrument. Fourth, the change statistics were recorded, revealing that because the $\Delta \chi^{2}(6.83)$, relative to the $\Delta d f(6)$, was non-significant (below the critical value of 12.59 ), the data were unaffected by endogeneity bias (Souchon et al., 2016). The study's results follow in the next section.

\section{Results}

The bivariate correlations are presented in Table 4. Turning to the model-testing stage, surprisingly, there was a negative and significant relationship between an entrepreneurial marketing orientation and financial performance. Thus, $\mathrm{H} 1$ was not supported. In addition, this link was positively and significantly moderated by coopetition. Therefore, support existed for H2. Moreover, there was varied support for the control variables, but more interesting, information related to the hypothesised paths (Table 5).

$$
\text { [Insert Tables } 4 \text { and } 5 \text { about here] }
$$

During the structural model, the squared multiple correlation showed that $49 \%$ of the variance of financial performance was explained. Likewise, the structural model fit indices were within the recommended thresholds $\left(X^{2}=451.86 ; d f=305 ; X^{2} / d f=1.48 ;\right.$ Sig. $=.00 ;$ RMSEA = .05; CFI = .97; IFI = .97; NNFI = .96; SRMR = .05). 
The "spotlight analysis" (Figure 2) revealed that that under low-levels of coopetition, the link between an entrepreneurial marketing orientation and financial performance was negative $(r=-0.15)$. Yet, under high-levels of coopetition, the slope became positive $(r=0.12)$. These results are discussed as follows.

[Insert Figure 2 about here]

\section{Discussion}

Prior to this current study, a growing interest existed concerning the performance-enhancing benefits of an entrepreneurial marketing orientation (Hills et al., 2008; Jones and Rowley, 2011; Hansen et al., 2020). That is, a cross-disciplinary field that can help owner-managers to leverage the advantages of a market orientation and an entrepreneurial orientation to yield higher-levels of performance (Morrish et al., 2010; Hultman and Hills, 2011; Miles et al., 2015). Although some research suggests that entrepreneurial marketing behaviours are likely to boost company performance (Sadiku-Dushi et al., 2019; Eggers et al., 2020), studies have typically overlooked certain moderating factors that might affect this relationship. Moreover, it is important to appreciate that from an entrepreneurial marketing perspective, respective owner-managers' perceptions towards performance are potentially subjective and their objectives such as those that exhibit 'lifestyle' goals in the tourism sector need recognition (see Crick et al., 2018). For this reason, the measurement scale in this current study allowed for a variance in the data by assuming that not all owner-managers had growth-oriented objectives (as per the pre-testing stage) and hence perceived performance was considered vis-à-vis competitors. Indeed, the pre-testing stage established that owner-managers considered this an appropriate measurement due to collaboration in the sector whereby they could benchmark their own performance against similar rivals.

At the same time, networking activities have been a prominent topic within the entrepreneurial marketing literature, since some smaller-sized businesses cooperate with certain stakeholders to achieve their goals (Boso et al., 2013; Whalen et al., 2016). Nevertheless, networking encapsulates a broad range of stakeholders (Bernal et al., 2002; Dana and Winstone, 2008; Felzensztein et al., 2010; 2019; Karami and Tang, 2019). An important business-to-business strategy related to this domain is coopetition, namely, collaboration among competitors 
(as per Bengtsson and Kock, 2014). That said however, it is unclear whether coopetition strengthens the performance outcomes of an entrepreneurial marketing orientation.

Consequently, drawing upon the resource-based view (Barney, 1991; 2018), this current study examined whether coopetition positively moderates the relationship between an entrepreneurial marketing orientation and financial performance. After undertaking an empirical study, the following key findings contribute to the existing body of knowledge. First, contrary to the extant literature, an entrepreneurial marketing orientation yielded a negative and significant link with financial performance. This was interesting because earlier investigations have suggested that these activities combine the benefits of a market orientation and an entrepreneurial orientation, which in turn, should allow small organisations to develop performance-enhancing strategies used to create customer value (Morris et al., 2002; Alqahtani and Uslay, 2020). This seemingly counter-intuitive result could be explained by there being certain drawbacks to a market orientation and an entrepreneurial orientation. For example, market-oriented strategies are often very expensive, since acquiring and processing market intelligence can take large-scale resources and capabilities that some small under-resourced firms may not possess (Slater and Narver, 1994). Likewise, some smaller-sized companies (such as those sampled within this current study) might be over-loaded with information about their customers and competitors, which could deplete their assets (Hodgkinson et al., 2012).

Moreover, an entrepreneurial orientation is not always a positive strategy, as owner-managers might pursue product-markets that fail, take poorly calculated risks, innovate in the wrong areas, and make other unwise decisions (see Wales et al., 2013; Hamzah et al., 2021). Since an entrepreneurial marketing orientation exists at the intersection between a market orientation and an entrepreneurial orientation (Baker and Sinkula, 2009), the possibility exists that owner-managers of some smaller-sized organisations might struggle to manage the complex factors that pertain to employing certain entrepreneurial marketing practices. Put another way, from the perspective of small businesses, when decision-makers "become entrenched in the product-markets in which they operate, they suffer from innovation resistance and technological inertia due to losing focus on breakthrough innovations that may develop new markets, lead to competitive advantages, and enhance new product 
development performance. Radical innovations are costly to develop and firms must tolerate the risk associated with them. As such, if signs from the market or consumers are not visible, the market-oriented firm may steer clear from these types of innovations and associated risks" (Morgan et al., 2015, p. 8). This suggests that a market orientation or an entrepreneurial orientation should drive financial performance, but not necessarily a combination of these firm-wide behaviours unless owner-managers can employ mechanisms like coopetition as discussed shortly. This negative and significant path to some degree challenges a range of earlier investigations that have concentrated on the merits of the marketing/entrepreneurship interface (see Morris et al., 2002; Miles et al., 2015; Eggers et al., 2020), offering new insights regarding how an entrepreneurial marketing orientation can be harmful for financial performance.

Second, coopetition positively and significantly moderated the relationship between an entrepreneurial marketing orientation and financial performance. This suggested that if managed effectively (see Raza-Ullah et al., 2014; Tidstrom, 2014), coopetition is a performance-enhancing networking activity that can allow decisionmakers to overcome some of the challenges associated with entrepreneurial marketing behaviours and improve their market-level success. In fact, it reinforces an issue made by various business-to-business scholars that cooperating with rivals can strengthen the performance outcomes of various activities (Ritala, 2012; Estrada and Dong, 2020). Rather than discussing networking in broad terms (Whalen et al., 2016; Alqahtani and Uslay, 2020), this result signifies that cooperating with rivals is one mechanism that can allow small under-resourced organisations to successfully implement an entrepreneurial marketing orientation. Essentially, this current study suggests there are conditional factors that determine the performance-related outcomes of entrepreneurial marketing behaviour (extending Sadiku-Dushi et al., 2019; Eggers et al., 2020).

Third, by incorporating coopetition into the entrepreneurial marketing domain, stronger insights have emerged on how the business-to-consumer and business-to-business domains can intersect. In this current study, coopetition surrounds organisations cooperating with their competitors to achieve mutually beneficial outcomes and not least in geographically close proximities (see Geldes et al., 2017; Felzenstein et al., 2018). This means that coopetition is an inter-firm partnership that can lead to customer-driven outcomes, such as satisfying the 
wants and needs of target markets (Crick and Crick, 2020). Although coopetition is a growing area of interest (Bengtsson and Kock, 2014; Hannah and Eisenhardt, 2018; Hoffmann et al, 2018), this current study offers new evidence into how smaller-sized companies can exploit these inter-firm partnerships. Fourth, while the resourcebased view is an established theory within the broader marketing literature (Morgan et al., 2009), the seminal roots of this perspective do not explore the relational factors that surround cooperative marketing strategies, like coopetition. By examining the more recent aspects of resource-based theory (focusing on the stakeholder dimension), this lens was applied to the collaborative and rivalrous facets of coopetition strategies and how they impact the performance outcomes of an entrepreneurial marketing orientation (responding Hunt and Derozier, 2004; Barney, 2018). Indeed, from an outside-in perspective (Day, 2014; Mu et al., 2018; Rust, 2020), this current study recognised the potential importance of market-led considerations via the need to collaborate with competitors rather than 'de-rail' them (see Day, 2014). Consistent with Priem and Butler (2001), simply the possession of resources/capabilities may not be enough to enhance performance and 'strategic flexibility' in identifying and exploiting opportunities is important. Not least, in respect of pivoting business models (as per Osterwalder and Pigneur, 2010; Gassmann et al., 2014). Indeed, as Hughes et al. (2020) suggest, decisionmakers should exhibit readiness to adapt to environmental circumstances. In the context of this current study, owner-managers' readiness may require under-resourced competitors to collaborate to overcome limitations in their respective business models (as per Crick and Crick, 2020). Some managerial recommendations follow in the next section.

\section{Managerial recommendations}

Alongside its theoretical contributions, this study offers the following recommendations for practitioners. First, although in principle it would make sense that an entrepreneurial marketing orientation should improve financial performance, this may not occur in practice if identified opportunities are not effectively exploited. The reason being is that pursuing certain opportunities can be time-consuming and costly; moreover, owner-managers may not have the strategic flexibility that is required. As a result, under-resourced owner-managers should operate within their means, but must avoid becoming over-loaded with market intelligence and pursuing the wrong 
product-markets. Second, despite an entrepreneurial marketing orientation being potentially harmful for financial performance if owner-managers do not possess and can act on an appropriate level of resources/capabilities, coopetition can help decision-makers to overcome such drawbacks if managed effectively.

That is, by working with complementary and trustworthy industry rivals, decision-makers can learn new ways to operate within their sectors and access effective resources and capabilities to enable them to pursue viable opportunities. Consequently, it follows that owner-managers of under-resourced smaller-sized organisations should recruit, train and incentivise employees to enable their respective firms to cooperate with their competitors to not simply increase their performance, but also, to avoid some of the negative aspects of entrepreneurial marketing practices. For example, gaining knowledge of not only the strengths and weaknesses of rivals but additionally which are appropriate competitors to collaborate with. In acting upon this knowledge, it is important to facilitate mutually beneficial, performance-enhancing advantages to sustain trustworthy and complementary relationships. In the hospitality and tourism context of this current study, one illustration is that this may involve joint referrals among partners as a business-to-business strategy to facilitate engagement with customers in a business-to-consumer context. This may encourage tourists to visit a region within a domestic context through to joint promotions for rivals entering markets that otherwise might be too expensive. Third, despite the advantages of coopetition, owner-managers of under-resourced small companies must always remember that it can be risky to share assets with competing businesses due to the potential for inter-firm tensions. Hence, it is suggested that decision-makers should collaborate with their competitors, but not to the extent where they are dependent on these networks to survive (let alone grow) within their industries. Otherwise, they might be at the mercy of their coopetition partners, rather than being able to operate on the basis of their own assets via an individualistic business model. Some limitations and avenues for future research follow in the next section.

\section{Limitations and avenues for future research}

While this current study has contributed to the extant literature, there are some limitations that facilitate certain directions for future research. First, although the final sample size of 184 observations was large enough to evaluate the elements of the conceptual framework, it was still somewhat small. Thus, in future research, it is 
recommended that academics should collect larger volumes of survey data to ensure that their results are generalisable. Second, self-reported scales were employed to operationalise the latent variables. Despite these being established measures (that passed all major robustness checks), it would have been useful to obtain a mixture of primary and secondary data. Hence, a direction for future research is to test similar models, with a combination of survey-based instruments and archival data (such as to measure financial performance).

Third, this current investigation was completely quantitative in its research design, with no qualitative insights to explain the statistical results apart from the pilot testing stage. Consequently, in the future, scholars may wish to conduct some follow-up interviews to explore the subjective and in-depth meanings behind their quantitative findings. This may include studies of a longitudinal nature subject to the ability to collect data over time. For example, what types of coopetition occurred and how did this manifest in regards to performance over time? What factors stimulated the coopetition and alternatively what barriers existed? How did these activities influence the decision-makers to either maintain or conclude the coopetition arrangements? These limitations were relatively minor, but nonetheless, allow this investigation to be revisited in future research. 


\section{References}

Adomako, S., Narteh, B., Danquah, J. and Analoui, F. (2016), "Entrepreneurial orientation in dynamic environments", International Journal of Entrepreneurial Behavior \& Research, Vol. 22 No. 5, pp. 616-642.

Alqahtani, N. and Uslay, C. (2020), "Entrepreneurial marketing and firm performance: synthesis and conceptual development", Journal of Business Research, Vol. 113 No. 1, pp. 62-71.

Barney, J.B. (1991), "Firm resources and sustained competitive advantage", Journal of Management, Vol. 17 No. 1, pp. 99-120.

Barney, J.B. (2001), "Is the resource-based "view" a useful perspective for strategic management research? Yes", Academy of Management Review, Vol. 26 No. 1, pp. 41-56.

Barney, J.B. (2018), "Why resource-based theory's model of profit appropriation must incorporate a stakeholder perspective", Strategic Management Journal, Vol. 39 No. 13, pp. 3305-3325.

Baker, W.E. and Sinkula, J.M. (2009), "The complementary effects of market orientation and entrepreneurial orientation on profitability in small businesses", Journal of Small Business Management, Vol. 47 No. 4, pp. 443-464.

Bell, J., Crick, D., and Young, S. (1998), "A holistic perspective on small firm growth and internationalisation", Academy of International Business Conference, City University, London.

Bengtsson, M. and Johansson, M. (2014), "Managing coopetition to create opportunities for small firms", International Small Business Journal, Vol. 32 No. 4, pp. 401-427.

Bengtsson, M. and Kock, S. (2014), "Coopetition - quo vadis? Past accomplishments and future challenges", Industrial Marketing Management, Vol. 43 No. 2, pp. 180-188.

Bengtsson, M., Raza-Ullah, T., and Vanyushyn, V. (2016), "The coopetition paradox and tension: the moderating role of coopetition capability", Industrial Marketing Management, Vol. 53 No. 1, pp. 19-30.

Bernal, S.M.H., Burr, C. and Johnsen, R.E. (2002), "Competitor networks: international competitiveness through collaboration", International Journal of Entrepreneurial Behavior \& Research, Vol. 8 No. 5, pp. 239-253.

Boso, N., Story, V.M. and Cadogan, J.W. (2013), "Entrepreneurial orientation, market orientation, network ties, and performance: study of entrepreneurial firms in a developing economy", Journal of Business Venturing, Vol. 28 No. 6, pp. 708-727.

Bouncken, R.B. and Kraus, S. (2013), "Innovation in knowledge-intensive industries: the double-edged sword of coopetition", Journal of Business Research, Vol. 66 No. 10, pp. 2060-2070.

Bouncken, R.B., Gast, J., Kraus, S., and Bogers, M. (2015), "Coopetition: a systematic review, synthesis, and future research directions", Review of Managerial Science, Vol. 9 No. 3, pp. 577-601.

Bouncken, R.B., Fredrich, V., Ritala, P. and Kraus, S. (2018), "Coopetition in new product development alliances: advantages and tensions for incremental and radical innovation", British Journal of Management, Vol. 29 No. 3, pp. 391-410.

Bouncken, R.B., Fredrich, V. and Kraus, S. (2020), "Configurations of firm-level value capture in coopetition", Long Range Planning, Vol. 53 No. 1, pp. 101869.

Cadogan, J.W. and Diamantopoulos, A. (1995), "Narver and Slater, Kohli and Jaworski and the market orientation construct: integration and internationalization", Journal of Strategic Marketing, Vol. 3 No. 1, pp. $41-60$. 
Cadogan, J.W., Kuivalainen, O. and Sundqvist, S. (2009), "Export market-oriented behavior and export performance: quadratic and moderating effects under differing degrees of market dynamism and internationalization", Journal of International Marketing, Vol. 17 No. 4, pp. 71-89.

Chaudhry, S. and Crick, D. (1998), "Export information providers: are they meeting the needs of SMEs?" Marketing Intelligence and Planning, Vol. 16 No. 3, pp. 141-149.

Chaudhry, S. and Crick, D. (2004), "The business practices of small Chinese restaurants in the U.K: an exploratory investigation", Journal of Strategic Change, Vol. 13 No. 1, pp. 37-49.

Chi, C.G. and Gursoy, D. (2009), "How to help your graduates secure better jobs? An industry perspective", International Journal of Contemporary Hospitality Management, Vol. 21 No. 3, pp. 308-322.

Chiambaretto, P., Bengtsson, M., Fernandez, A-S. and Näsholm, N.H. (2020), "Small and large firms' trade-off between benefits and risks when choosing a coopetitor for innovation”, Long Range Planning, Vol. 53 No. 1, pp. 101876.

Churchill Jr., G.A. (1979), "A paradigm for developing better measures of marketing constructs", Journal of Marketing Research, Vol. 16 No. 1, pp. 64-73.

Covin, J.G. and Slevin, D.P. (1989), "Strategic management of small firms in hostile and benign environments", Strategic Management Journal, Vol. 10 No. 1, pp. 75-87.

Crick, D. (1992), "UK export assistance: are we supporting the best programmes?" Journal of Marketing Management, Vol. 8 No. 1, pp. 81-92.

Crick, D. and Chaudhry, S. (2000), 'UK SMEs' awareness, use, and perceptions of selected government export assistance: an investigation into the effect of ethnicity", International Journal of Entrepreneurial Behaviour \& Research, Vol. 6 No. 2, pp. 72-89.

Crick, D., Chaudhry, S., and Crick, J.M. (2016), "Trading in a competitive environment: South-Asian restaurants in the UK", Strategic Change, Vol. 25 No. 4, pp. 371-382.

Crick, D., Chaudhry, S. and Crick, J.M. (2018), "Risks/rewards and an evolving business model: a case study of a small lifestyle business in the UK tourism sector", Qualitative Marketing Research: An International Journal, Vol. 21 No. 2, pp. 143-165.

Crick, D. and Crick, J.M. (2015), "Learning and decision making in marketing planning: a study of New Zealand vineyards", Marketing Intelligence and Planning, Vol. 33 No. 5, pp. 707-732.

Crick, D. and Crick, J.M. (2016a), "The first export order: a marketing innovation revisited", Journal of Strategic Marketing, Vol. 24 No. 2, pp. 77-89.

Crick, J.M. (2015), Bridging the gap between threshold and dynamic capabilities: a qualitative study of the collaboration strategies of New Zealand wineries, Unpublished Master of Business Studies Thesis, Massey University, Wellington, New Zealand.

Crick, J.M. (2020), "The dark side of coopetition: when collaborating with competitors is harmful for company performance", Journal of Business \& Industrial Marketing, Vol. 35 No. 2, pp. 318-337.

Crick, J.M. (2021), "Unpacking the relationship between a coopetition-oriented mind-set and coopetition-oriented behaviours," Journal of Business \& Industrial Marketing, https://doi.org/10.1108/JBIM-03-2020-0165.

Crick, J.M. and Crick, D. (2016b), "Developing entrepreneurial resilience in the UK tourism sector", Strategic Change, Vol. 25 No. 3, pp. 315-325. 
Crick, J.M. and Crick, D. (2018), "Angel investors' predictive and control funding criteria: the importance of evolving business models," Journal of Research in Marketing and Entrepreneurship, Vol. 20 No. 1, pp. 3456 .

Crick, J.M. and Crick, D. (2019), "Developing and validating a multi-dimensional measure of coopetition", Journal of Business \& Industrial Marketing, Vol. 34 No. 4, pp. 665-689.

Crick, J.M. and Crick, D. (2020), "Coopetition and COVID-19: collaborative business-to-business marketing strategies in a pandemic crisis", Industrial Marketing Management, Vol. 88 No. 1, pp. 206-213.

Crick, J.M. and Crick, D. (2021), "Coopetition and sales performance: evidence from non-mainstream sporting clubs", International Journal of Entrepreneurial Behavior \& Research, Vol. 27 No. 1, pp. 123-147.

Czakon, W. and Czernek, K. (2016), "The role of trust-building mechanisms in entering into network coopetition: the case of tourism networks in Poland", Industrial Marketing Management, Vol. 57 No. 1, pp. 64-74.

Czakon, W., Srivastava, M.K., Le Roy, F. and Gnyawali, D.R. (2020), "Coopetition strategies: critical issues and research directions", Long Range Planning, Vol. 53 No. 1, pp. 101948.

Czernek, K., Czakon, W. and Marszałek, P. (2017), "Trust and formal contracts: complements or substitutes? A study of tourism collaboration in Poland", Journal of Destination Marketing \& Management, Vol. 6 No. 4, pp. 318-326.

Dana, L-P. and Winstone, K.E. (2008), "Wine cluster formation in New Zealand: operation, evolution and impact", International Journal of Food Science and Technology, Vol. 43 No. 12, pp. 2177-2190.

Dana, L-P., Granata, J., Lasch, F. and Carnaby, A. (2013), "The evolution of co-opetition in the Waipara wine cluster of New Zealand", Wine Economics and Policy, Vol. 2 No. 1, pp. 42-49.

Day, G.S. (2014), "An outside-in approach to resource-based theories", Journal of the Academy of Marketing Science, Vol. 42 No. 1, pp. 27-28.

Eggers, F., Niemand, T., Kraus, S. and Breier, M. (2020), "Developing a scale for entrepreneurial marketing: revealing its inner frame and prediction of performance", Journal of Business Research, Vol. 113 No. 1, pp. $72-82$.

Estrada, I. and Dong, J.Q. (2020), "Learning from experience? Technological investments and the impact of coopetition experience on firm profitability", Long Range Planning, Vol. 53 No. 1, pp. 101866.

Felzensztein, C., Gimmon, E. and Carter, S. (2010), "Geographical co-location, social networks and inter-firm marketing co-operation: the case of the salmon industry", Long Range Planning, Vol. 43 Nos. 5/6, pp. 675690.

Felzensztein, C., Gimmon, E. and Deans, K.R. (2018), "Coopetition in regional clusters: keep calm and expect unexpected changes", Industrial Marketing Management, Vol. 69 No. 1, pp. 116-124.

Felzensztein, C., Deans, K.R. and Dana, L-P. (2019), "Small firms in regional clusters: local networks and internationalization in the Southern Hemisphere", Journal of Small Business Management, Vol. 57 No. 2, pp. 496-516.

Ferreira, J.J.M., Fernandes, C.I., and Kraus, S. (2019), "Entrepreneurship research: mapping intellectual structures and research trends", Review of Managerial Science, Vol. 13 No. 1, pp. 181-205.

Fornell, C. and Larcker, D.F. (1981), "Structural equation models with unobservable variables and measurement error: algebra and statistics", Journal of Marketing Research, Vol. 18 No. 3, pp. 382-388.

Gassmann, O., Frankenberger, K. and Csik, M. (2014), The Business Model Navigator. FT Publishing: Harlow. 
Geldes, C., Heredia, J., Felzensztein, C. and Mora, M. (2017), "Proximity as determinant of business cooperation for technological and non-technological innovations: a study of an agribusiness cluster", Journal of Business \& Industrial Marketing, Vol. 32 No. 1, pp. 167-178.

Granata, J., Lasch, F., Le Roy, F. and Dana, L-P. (2018), "How do micro-firms manage coopetition? A study of the wine sector in France", International Small Business Journal, Vol. 36 No. 3, pp. 331-355.

Guo, X. (2013), "Living in a global world: influence of consumer global orientation on attitudes toward global brands from developed versus emerging countries", Journal of International Marketing, Vol. 21 No. 1, pp. $1-22$.

Hagtvedt, H. (2011), "The impact of incomplete typeface logos on perceptions of the firm", Journal of Marketing, Vol. 75 No. 4, pp. 86-93.

Hannah, D.P. and Eisenhardt, K.M. (2018), "How firms navigate cooperation and competition in nascent ecosystems", Strategic Management Journal, Vol. 39 No. 12, pp. 3163-3192.

Hamzah, M.I, Crick, J.M., Crick, D., Ali, S.A.M., and Yunus, N.M. (2021), "The nature of the relationship between an entrepreneurial marketing orientation and small business growth: evidence from Malaysia", International Journal of Entrepreneurship and Small Business, Earlycite.

Hansen, D.J. and Eggers, F. (2010), "The marketing/entrepreneurship interface: a report on the "Charleston Summit"' Journal of Research in Marketing and Entrepreneurship, Vol. 12 No. 1, pp. 42-53.

Hansen, D.J., Deacon, J.H., Pascal, V.J. and Sethna, Z. (2020), "The future is in the past: a framework for the marketing-entrepreneurship interface (MEI)", Journal of Business Research, Vol. 113 No. 1, pp. 198-208.

Hills, G.E. and LaForge, R.W. (1992), "Research at the marketing interface to advance entrepreneurship theory", Entrepreneurship Theory \& Practice, Vol. 16 No. 3, pp. 91-100.

Hills, G.E., Hultman, C.M. and Miles, M.P. (2008), "The evolution and development of entrepreneurial marketing", Journal of Small Business Management, Vol. 46 No. 1, pp. 99-112.

Hills, G.E. and Hultman, C.M. (2011), "Academic roots: the past and present of entrepreneurial marketing", Journal of Small Business \& Entrepreneurship, Vol. 24 No. 1, pp. 1-10.

Hodgkinson, I.R., Hughes, P. and Hughes, M. (2012), "Re-examining the deployment of market orientation in the public leisure sector", Journal of Marketing Management, Vol. 28 Nos. 11/12, pp. 1249-1269.

Hoffmann, W., Lavie, D., Reuer, J.J. and Shipilov, A. (2018), "The interplay of competition and cooperation", Strategic Management Journal, Vol. 39 No. 12, pp. 3033-3052.

Hughes P., Morgan R.E., Hodgkinson, I.R., Kouropalatis, Y. and Lindgreen, A. (2020), "A diagnostic tool to determine a strategic improvisation readiness index score (IRIS) to survive, adapt, and thrive in a crisis", Industrial Marketing Management, Vol. 88 No. July, pp. 485-499.

Hult, G.T.M. and Ketchen Jr., D.J. (2001), "Does market orientation matter? A test of the relationship between positional advantage and performance", Strategic Management Journal, Vol. 22 No. 9, pp. 899-906.

Hultman, C.M. and Hills, G.E. (2011), "Influence from entrepreneurship in marketing theory", Journal of Research in Marketing, Vol. 13 No. 2, pp. 120-125.

Hultman, M., Robson, M.J. and Katsikeas, C.S. (2009), "Export product strategy fit and performance: an empirical investigation", Journal of International Marketing, Vol. 17 No. 4, pp. 1-23.

Hunt, S.D. and Derozier, C. (2004), "The normative imperatives of business and marketing strategy: grounding strategy in resource-advantage theory", Journal of Business \& Industrial Marketing, Vol. 19 No. 1, pp. 5-22. 
Hunt, S.D. and Morgan, R.M. (1995), "The comparative advantage theory of competition", Journal of Marketing, Vol. 59 No. 2, pp. 1-15.

Hunt, S.D., Sparkman Jr., R.D. and Wilcox, J.B. (1982), "The pre-test in survey research: issues and preliminary findings", Journal of Marketing Research, Vol. 19 No. 2, pp. 269-273.

Irwin, J.R. and McClelland, G.H. (2001), "Misleading heuristics and moderated multiple regression models", Journal of Marketing Research, Vol. 38 No. 1, pp. 100-109.

Jaworski, B.J. and Kohli, A.K. (1993), "Market orientation: antecedents and consequences", Journal of Marketing, Vol. 57 No. 3, pp. 53-70.

Josephson, B.W., Johnson, J.L. and Mariadoss, B.J. (2016), "Strategic marketing ambidexterity: antecedents and financial consequences", Journal of the Academy of Marketing Science, Vol. 44 No. 4, pp. 539-554.

Jones, R. and Rowley, J. (2011), "Entrepreneurial marketing in small businesses: a conceptual exploration", International Small Business Journal, Vol. 29 No. 1, pp. 25-36.

Kahiya, E.T., Dean, D., and Heyl, J. (2014), "The dynamic nature of the export development undertaking: implications for researchers and practitioners". Research Handbook on Export Marketing, Edward Elgar Publishing, Chapter 9: 203-230.

Kahiya, E.T. (2020), "Context in international business: entrepreneurial internationalization from a distant small open economy", International Business Review, Vol. 29 No. 1, pp. 101621.

Karami M. and Tang, J. (2019), "Entrepreneurial orientation and SME international performance: The mediating role of networking capability and experiential learning", International Small Business Journal, Vol. 37 No. 2, pp. 105-124.

Kellermanns, F., Walter, J., Crook, T.R., Kemmerer, B. and Narayanan, V. (2016), "The resource-based view in entrepreneurship: a content-analytical comparison of researchers' and entrepreneurs' views", Journal of Small Business Management, Vol. 54 No. 1, pp. 26-48.

Kohli, A.K. and Jaworski, B.J. (1990), "Market orientation: the construct, research propositions, and managerial implications", Journal of Marketing, Vol. 54 No. 2, pp. 1-18.

Kraus, S., Klimas, P., Gast, J. and Stephan, T. (2019), "Sleeping with competitors: forms, antecedents and outcomes of coopetition of small and medium-sized craft beer breweries", International Journal of Entrepreneurial Behavior \& Research, Vol. 25 No. 1, pp. 50-66.

Lavie, D. (2006), "The competitive advantage of inter-connected firms: an extension of the resource-based view", Academy of Management Review, Vol. 31 No. 3, pp. 638-658.

Lindell, M.K. and Whitney, D.J. (2001), "Accounting for common method variance in cross-sectional research designs", Journal of Applied Psychology, Vol. 86 No. 1, pp. 114-121.

Liu, W., Guillet, B.D., Xiao, Q. and Law, R. (2014), "Globalization or localization of consumer preferences: the case of hotel room booking", Tourism Management, Vol. 41 No. 1, pp. 148-157.

Lumpkin, G.T. and Dess, G.G. (1996), "Clarifying the entrepreneurial orientation construct and linking it to performance", Academy of Management Review, Vol. 21 No. 1, pp. 135-172.

MBIE, Ministry of Business, Innovation and Employment (2020), https://www.mbie.govt.nz/business-andemployment/business/support-for-business/small-business/, accessed various dates.

Miles, M.P., Gilmore, A., Harrigan, P., Lewis, G. and Sethna, Z. (2015), "Exploring entrepreneurial marketing", Journal of Strategic Marketing, Vol. 23 No. 2, pp. 94-111. 
Moorman, C. (1995), "Organizational market information processes: cultural antecedents and new product outcomes", Journal of Marketing Research, Vol. 32 No. 3, pp. 318-335.

Morgan, N.A., Vorhies, D.W. and Mason, C.H. (2009), "Market orientation, marketing capabilities, and firm performance", Strategic Management Journal, Vol. 30 No. 8, pp. 909-920.

Morgan, R.M. and Hunt, S.D. (1994), "The commitment-trust theory of relationship marketing", Journal of Marketing, Vol. 58 No. 3, pp. 20-38.

Morgan, T., Anokhin, S. and Wincent, J. (2016), "Entrepreneurial orientation, firm market power and opportunism in networks", Journal of Business \& Industrial Marketing, Vol. 31 No. 1, pp. 99-111.

Morgan, T., Anokhin, S., Kretinin, A. and Frishammar, J. (2015), "The dark-side of the entrepreneurial orientation and market orientation interplay: a new product development perspective", International Small Business Journal, Vol. 33 No. 7, pp. 731-751.

Moriarty, J., Jones, R., Rowley, J. and Kupiec-Teahan, B. (2008), "Marketing in small hotels: a qualitative study", Marketing Intelligence \& Planning, Vol. 26 No. 3, pp. 293-315.

Morrish, S.C., Miles, M.P. and Deacon, J.H. (2010), "Entrepreneurial marketing: acknowledging the entrepreneur and customer-centric interrelationship", Journal of Strategic Marketing, Vol. 18 No. 4, pp. 303-316.

Morrish, S.C., Eggers, F., Pattinson, H. and Hills, G.E. (2020), "Three decades in the making: the evolution of entrepreneurial marketing", Journal of Business Research, Vol. 113 No. 1, pp. 59-61.

Morris, M.H., Schindehutte, M. and LaForge, R.W. (2002), "Entrepreneurial marketing: a construct for integrating emerging entrepreneurship and marketing perspectives", Journal of Marketing Theory and Practice, Vol. 10 No. 4, pp. 1-19.

Mu, J., Bao, Y., Sekhon, T., Qi, J., and Love, E. (2018), "Outside-in marketing capability and firm performance", Industrial Marketing Management, Vol. 75 No. 1, pp. 37-54.

Narver, J.C. and Slater, S.F. (1990), "The effect of a market orientation on business profitability", Journal of Marketing, Vol. 54 No. 4, pp. 20-35.

Nason, R.S. and Wiklund, J. (2018), "An assessment of resource-based theorizing on firm growth and suggestions for the future", Journal of Management, Vol. 44 No. 1, pp. 32-60.

NZTE, New Zealand Trade \& Enterprise (2020), https://www.nzte.govt.nz/page/tourism, accessed on various dates.

Osterwalder, A. and Pigneur, Y. (2010), Business Model Generation. Wiley: New Jersey.

Peter, J.P. (1981), "Construct validity: a review of basic issues and marketing practices", Journal of Marketing Research, Vol. 18 No. 2, pp. 133-145.

Peterson, R.A. (2000), "A meta-analysis of variance accounted for and factor loadings in exploratory factor analysis", Marketing Letters, Vol. 11 No. 3, pp. 261-275.

Podsakoff, P.M., Mackenzie, S.B., Lee, J.Y. and Podsakoff, N.P. (2003), "Common method biases in behavioral research: a critical review of the literature and recommended remedies", Journal of Applied Psychology, Vol. 88 No. 5, pp. 879-903.

Powers, T.L., Kennedy, K.N. and Choi, S. (2020), "Market orientation and performance: industrial supplier and customer perspectives", Journal of Business \& Industrial Marketing, Vol. 35 No. 11, pp. 1701-1714

Priem, R.L. and Butler, J.E. (2001), "Is the resource-based view a useful perspective for strategic management research?", Academy of Management Review, Vol. 26 No. 1, pp. 22-40. 
Ray, G., Barney, J.B. and Muhanna, W.A. (2004), "Capabilities, business processes, and competitive advantage: choosing the dependent variable in empirical tests of the resource-based view", Strategic Management Journal, Vol. 25 No. 1, pp. 23-37.

Raza-Ullah, T., Bengtsson, M., and Kock, S. (2014), "The coopetition paradox and tension in coopetition at multiple-levels", Industrial Marketing Management, Vol. 43 No. 2, pp. 189-198.

Reynolds, N. and Diamantopoulos, A. (1998), "The effect of pre-test method on error detection rates: experimental evidence", European Journal of Marketing, Vol. 32 No. 5-6, pp. 480-498.

Ritala, P. (2012), "Coopetition strategy - when is it successful? Empirical evidence on innovation and market performance", British Journal of Management, Vol. 23 No. 3, pp. 307-324.

Roundy, P.T. (2017), "Doing good" while serving customers. Charting the social entrepreneurship and marketing interface", Journal of Research in Marketing and Entrepreneurship, Vol. 19 No. 2, pp. 105-124.

Rust, R.T. (2020), "Outside-in marketing: why, when and how?", Industrial Marketing Management, Vol. 89 No. Aug, pp. 102-104.

Sadiku-Dushi, N., Dana, L-P. and Ramadani, V. (2019), "Entrepreneurial marketing dimensions and SMEs performance", Journal of Business Research, Vol. 100 No. 1, pp. 86-99.

Slater, S.F. and Narver, J.C. (1994), "Does competitive environment moderate the market orientationperformance relationship?", Journal of Marketing, Vol. 58 No. 1, pp. 46-55.

Souchon, A.L., Hughes, P., Farrell, A.M., Nemkova, E. and Oliveira, J.S. (2016), "Spontaneity and international marketing performance", International Marketing Review, Vol. 33 No. 5, pp. 671-690.

Sundqvist, S., Kylaheiko, K., Kuivalainen, O. and Cadogan, J.W. (2012), "Kirznerian and Schumpeterian entrepreneurial-oriented behavior in turbulent export markets", International Marketing Review, Vol. 29 No. 2, pp. 203-219.

Thomas, L.C., Painbeni, S. and Barton, H. (2013), "Entrepreneurial marketing within the French wine industry", International Journal of Entrepreneurial Behavior \& Research, Vol. 19 No. 2, pp. 238-260.

Tidstrom, A. (2014), "Managing tensions in coopetition", Industrial Marketing Management, Vol. 43 No. 2, pp. 261-271.

Tourism New Zealand (2020), https://www.tourismnewzealand.com/about/about-the-tourism-industy/, accessed on various dates.

Vatsa, P. (2020), "Co-movement amongst the demand for New Zealand tourism", Annals of Tourism Research, Vol. 83 No. July, pp. 102965

Velu, C. (2016), "Evolutionary or revolutionary business model innovation through coopetition? The role of dominance in network markets", Industrial Marketing Management, Vol. 53 No. 1, pp. 124-135.

Vorhies, D.W., Orr, L.M. and Bush, V.D. (2011), "Improving customer-focused marketing capabilities and firm financial performance via marketing exploration and exploitation", Journal of the Academy of Marketing Science, Vol. 39 No. 5, pp. 736-756.

Wales, W.J., Gupta, V.K. and Mousa, F-T. (2013), "Empirical research on entrepreneurial orientation: an assessment and suggestions for future research", International Small Business Journal, Vol. 31 No. 4, pp. 357-383. 
Wales, W.J., Kraus, S., Filser, M., Stöckmann, C., and Covin, J.G. (2021), "The status quo of research on entrepreneurial orientation: conversational landmarks and theoretical scaffolding", Journal of Business Research, in press; DOI: https://doi.org/10.1016/j.jbusres.2020.10.046.

Whalen, P., Uslay, C., Pascal, V.J., Omura, G., McAuley, A., Kasouf, C.J., Jones, R., Hultman, C.M., Hills, G.E., Hansen, D.J., Gilmore, A., Giglierano, J., Eggers, F. and Deacon, J.H. (2016), "Anatomy of competitive advantage: towards a contingency theory of entrepreneurial marketing", Journal of Strategic Marketing, Vol. 24 No. 1, pp. 5-19.

Wiklund, J. and Shepherd, D.A. (2005), "Entrepreneurial orientation and small business performance: a configurational approach", Journal of Business Venturing, Vol. 20 No. 1, pp. 71-91.

Yan, Y., Dong, J.Q. and Faems, D. (2020), "Not every coopetitor is the same: the impact of technological, market and geographical overlap with coopetitors on firms' breakthrough inventions", Long Range Planning, Vol. 53 No. 1, pp. 101873. 
Figure 1. Conceptual model

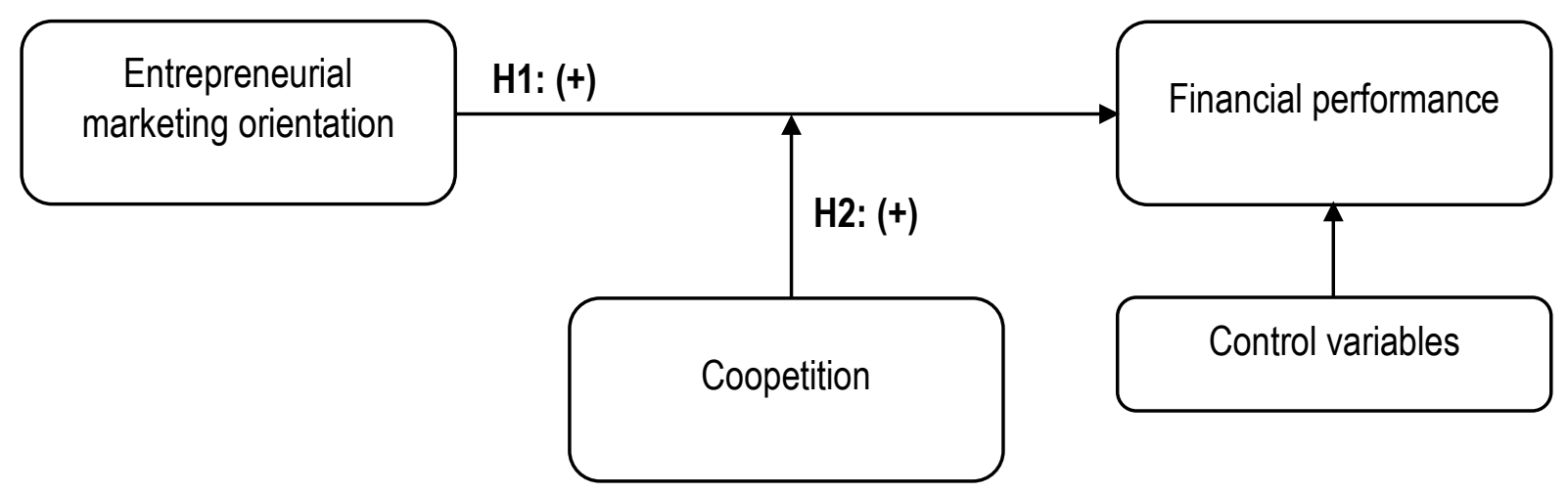

The control variables were firm size, firm age, degree of internationalisation, the facets of a market orientation (intelligence generation, intelligence dissemination, and intelligence responsiveness), and the dimensions of an entrepreneurial orientation (innovativeness, proactiveness, risk-taking, autonomy, and competitive aggressiveness)

Figure 2. Moderating effects from coopetition

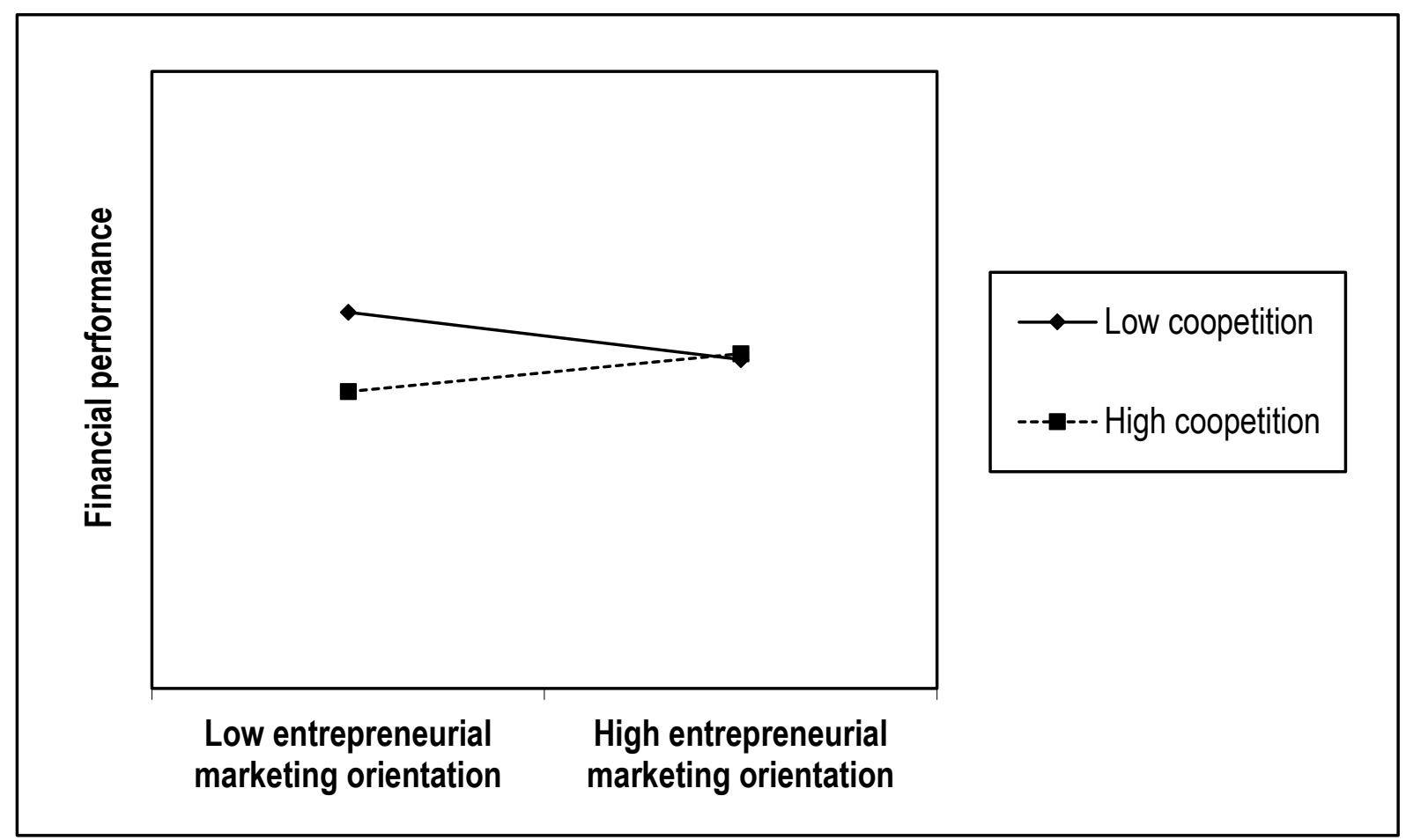


Table 1. Regional locations of the final sample

\begin{tabular}{|l|c|c|}
\hline Regions & Frequency & Percent (\%) \\
\hline Bay of Islands and Northland & 3 & 1.6 \\
\hline Auckland & 63 & 33.3 \\
\hline The Coromandel & 1 & 0.5 \\
\hline Hamilton and Waikato & 9 & 4.9 \\
\hline Bay of Plenty & 12 & 6.5 \\
\hline Rotorua & 5 & 2.7 \\
\hline Eastland & 1 & 0.5 \\
\hline Lake Taupo & 1 & 0.5 \\
\hline Taranaki & 2 & 1.1 \\
\hline Whanganui & 1 & 0.5 \\
\hline Hawkes Bay & 7 & 3.8 \\
\hline Manawatu & 5 & 3.7 \\
\hline Wairarapa & 2 & 1.1 \\
\hline Wellington & 15 & 8.2 \\
\hline Nelson and Tasman & 4 & 2.2 \\
\hline Marlborough & 2 & 1.1 \\
\hline Christchurch and Canterbury & 15 & 8.2 \\
\hline Dunedin & 6 & 3.3 \\
\hline Southland & 5 & 2.7 \\
\hline Queenstown & 25 & 13.6 \\
\hline TOTAL & 184 & 100.0 \\
\hline Note: The final sample was comprised of smaller-sized firms - which represented the main tourism \\
and hospitality regions of New Zealand (urban and rural areas). & \\
\hline
\end{tabular}


Table 2. Exploratory factor analysis model

\begin{tabular}{|c|c|c|c|c|c|c|c|c|c|c|c|}
\hline & \multicolumn{11}{|c|}{ Factors } \\
\hline Items & 1. & 2. & 3. & 4. & 5. & 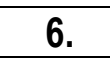 & 7. & 8. & 9. & 10. & 11. \\
\hline GN1 & 0.66 & 0.18 & 0.35 & 0.23 & 0.06 & 0.00 & 0.09 & 0.02 & 0.10 & 0.12 & 0.14 \\
\hline GN3 & 0.56 & 0.29 & 0.13 & 0.28 & 0.06 & 0.03 & 0.03 & 0.25 & 0.18 & 0.18 & 0.19 \\
\hline DS1 & 0.05 & 0.77 & 0.17 & 0.26 & 0.18 & 0.05 & 0.07 & 0.03 & 0.02 & 0.01 & 0.16 \\
\hline DS2 & 0.29 & 0.73 & 0.08 & 0.11 & 0.09 & 0.00 & 0.15 & 0.04 & 0.06 & 0.11 & 0.26 \\
\hline DS3 & 0.14 & 0.69 & 0.10 & 0.19 & 0.00 & 0.11 & 0.03 & 0.06 & 0.06 & 0.21 & 0.34 \\
\hline RP1 & 0.07 & 0.08 & 0.79 & 0.23 & 0.02 & 0.04 & 0.07 & 0.18 & 0.21 & 0.07 & 0.14 \\
\hline RP2 & 0.27 & 0.12 & 0.70 & 0.09 & 0.23 & 0.09 & 0.11 & 0.01 & 0.14 & 0.16 & 0.13 \\
\hline RP3 & 0.20 & 0.15 & 0.73 & 0.09 & 0.18 & 0.07 & 0.16 & 0.10 & 0.20 & 0.07 & 0.04 \\
\hline IN1 & 0.08 & 0.27 & 0.13 & 0.66 & 0.13 & 0.15 & 0.20 & 0.09 & 0.16 & 0.28 & 0.11 \\
\hline IN2 & 0.19 & 0.09 & 0.16 & 0.62 & 0.24 & 0.19 & 0.28 & 0.06 & 0.16 & 0.23 & 0.09 \\
\hline IN3 & 0.16 & 0.21 & 0.14 & 0.69 & 0.09 & 0.10 & 0.13 & 0.18 & 0.23 & 0.18 & 0.04 \\
\hline IN4 & 0.03 & 0.07 & 0.11 & 0.66 & 0.17 & 0.15 & 0.02 & 0.13 & 0.27 & 0.29 & 0.06 \\
\hline IN5 & 0.06 & 0.15 & 0.09 & 0.75 & 0.17 & 0.11 & 0.04 & 0.13 & 0.21 & 0.10 & 0.13 \\
\hline PT1 & 0.05 & 0.13 & 0.28 & 0.11 & 0.66 & 0.24 & 0.18 & 0.15 & 0.09 & 0.05 & 0.01 \\
\hline PT2 & 0.01 & 0.01 & 0.00 & 0.29 & 0.76 & 0.00 & 0.02 & 0.08 & 0.10 & 0.13 & 0.30 \\
\hline PT3 & 0.07 & 0.18 & 0.12 & 0.19 & 0.78 & 0.22 & 0.03 & 0.04 & 0.02 & 0.18 & 0.04 \\
\hline RK1 & 0.06 & 0.04 & 0.02 & 0.07 & 0.10 & 0.82 & 0.01 & 0.15 & 0.23 & 0.23 & 0.16 \\
\hline RK2 & 0.05 & 0.04 & 0.01 & 0.19 & 0.08 & 0.7 & 0.10 & 0.20 & 0.26 & 0.22 & 0.00 \\
\hline RK3 & 0.10 & 0.06 & 0.07 & 0.28 & 0.23 & 0.76 & 0.07 & 0.21 & 0.23 & 0.12 & 0.02 \\
\hline $\mathrm{AO1}$ & 0.18 & 0.05 & 0.17 & 0.20 & 0.04 & 0.03 & 0.73 & 0.15 & 0.06 & 0.10 & 0.20 \\
\hline $\mathrm{AO2}$ & 0.00 & 0.16 & 0.02 & 0.02 & 0.08 & 0.07 & 0.82 & 0.12 & 0.06 & 0.10 & 0.11 \\
\hline $\mathrm{AO3}$ & 0.29 & 0.01 & 0.01 & 0.14 & 0.08 & 0.02 & 0.78 & 0.13 & 0.01 & 0.01 & 0.11 \\
\hline CA1 & 0.04 & 0.03 & 0.05 & 0.13 & 0.01 & 0.1 & 0.10 & 0.87 & 0.15 & 0.01 & 0.10 \\
\hline CA2 & 0.03 & 0.03 & 0.11 & 0.14 & 0.03 & 0.09 & 0.20 & 0.81 & 0.24 & 0.00 & 0.14 \\
\hline CA3 & 0.00 & 0.04 & 0.08 & 0.11 & 0.10 & & 0.12 & 0.86 & 0.18 & 0.03 & 0.05 \\
\hline $\mathrm{CO1}$ & 0.11 & 0.04 & 0.13 & 0.18 & 0.06 & 0.1 & 0.09 & 0.21 & 0.77 & 0.09 & 0.10 \\
\hline $\mathrm{CO} 2$ & 0.12 & 0.12 & 0.01 & 0.17 & 0.01 & 0.19 & 0.02 & 0.19 & 0.77 & 0.07 & 0.14 \\
\hline $\mathrm{CO} 3$ & 0.06 & 0.07 & 0.16 & 0.14 & 0.04 & 0.21 & 0.02 & 0.06 & 0.81 & 0.07 & 0.00 \\
\hline $\mathrm{CO} 4$ & 0.11 & 0.07 & 0.05 & 0.30 & 0.00 & & 0.01 & 0.11 & 0.82 & 0.00 & 0.03 \\
\hline $\mathrm{CO}$ & 0.03 & 0.03 & 0.20 & 0.01 & 0.11 & 0.01 & 0.02 & 0.09 & 0.79 & 0.17 & 0.10 \\
\hline PF1 & 0.02 & 0.07 & 0.03 & 0.26 & 0.06 & 0.10 & 0.01 & 0.01 & 0.06 & 0.81 & 0.21 \\
\hline $\mathrm{PF} 2$ & 0.09 & 0.06 & 0.07 & 0.15 & 0.08 & 0.03 & 0.08 & 0.02 & 0.01 & 0.74 & 0.18 \\
\hline PF3 & 0.22 & 0.11 & 0.12 & 0.00 & 0.13 & & 0.05 & 0.04 & 0.13 & 0.73 & 0.09 \\
\hline PF4 & 0.01 & 0.14 & 0.1 & 0.03 & 0.22 & 0.14 & 0.08 & 0.04 & 0.09 & 0.83 & 0.02 \\
\hline PF5 & 0.09 & 0.06 & 0.03 & 0.28 & 0.08 & 0.09 & 0.00 & 0.05 & 0.12 & 0.81 & 0.16 \\
\hline IQ1 & 0.11 & 0.12 & 0.03 & 0.04 & 0.16 & 0.06 & 0.06 & 0.02 & 0.05 & 0.22 & 0.82 \\
\hline IQ2 & 0.09 & 0.08 & 0.06 & 0.05 & 0.10 & 0.1 & 0.10 & 0.11 & 0.03 & 0.09 & 0.83 \\
\hline IQ3 & 0.05 & 0.08 & 0.02 & 0.11 & 0.02 & 0.10 & 0.18 & 0.02 & 0.00 & 0.08 & 0.77 \\
\hline IQ4 & 0.01 & 0.11 & 0.00 & 0.04 & 0.06 & 0.05 & 0.03 & 0.04 & 0.10 & 0.07 & 0.84 \\
\hline IQ5 & 0.09 & 0.18 & 0.17 & 0.06 & 0.01 & 0.04 & 0.04 & 0.13 & 0.08 & 0.09 & 0.78 \\
\hline
\end{tabular}


Table 3. Final multi-item scales

\begin{tabular}{|c|c|c|c|c|c|c|}
\hline $\begin{array}{l}\text { Multi-item } \\
\text { measures }\end{array}$ & $\begin{array}{c}\text { Mean (standard } \\
\text { deviation) }\end{array}$ & $\begin{array}{c}\text { Standardised factor } \\
\text { loadings }\end{array}$ & $\begin{array}{l}\text { Standardised error } \\
\text { variances }\end{array}$ & $\begin{array}{c}\text { Internal } \\
\text { consistency }\end{array}$ & $\begin{array}{l}\text { Composite } \\
\text { reliability }\end{array}$ & $\begin{array}{c}\text { Average variance } \\
\text { extracted }\end{array}$ \\
\hline IN & $4.83(1.44)$ & $0.83-0.86$ & $0.26-0.36$ & 0.87 & 0.87 & 0.69 \\
\hline PT & $4.88(1.11)$ & $0.71-0.81$ & $0.35-0.49$ & 0.79 & 0.79 & 0.56 \\
\hline RK & $3.90(1.55)$ & $0.87-0.88$ & $0.22-0.23$ & 0.91 & 0.91 & 0.77 \\
\hline $\mathrm{AO}$ & $4.72(1.31)$ & $0.75-0.78$ & $0.39-0.44$ & 0.74 & 0.74 & 0.59 \\
\hline $\mathrm{CA}$ & $3.71(1.65)$ & $0.88-0.90$ & $0.19-0.23$ & 0.91 & 0.92 & 0.78 \\
\hline GN & $5.17(1.19)$ & $0.54-0.97$ & $0.05-0.71$ & 0.68 & 0.75 & 0.62 \\
\hline DS & $5.27(1.12)$ & $0.79-0.81$ & $0.35-0.38$ & 0.78 & 0.78 & 0.64 \\
\hline $\mathrm{RP}$ & $5.08(1.25)$ & $0.79-0.81$ & $0.35-0.37$ & 0.78 & 0.78 & 0.64 \\
\hline $\mathrm{CO}$ & $4.10(1.48)$ & $0.72-0.88$ & $0.22-0.48$ & 0.88 & 0.88 & 0.65 \\
\hline $\mathrm{PF}$ & $4.96(1.10)$ & $0.79-0.91$ & $0.17-0.37$ & 0.90 & 0.90 & 0.75 \\
\hline $\mathrm{IQ}$ & $5.89(1.11)$ & $0.80-0.85$ & $0.28-0.36$ & 0.86 & 0.86 & 0.68 \\
\hline
\end{tabular}


Table 4. Bivariate correlations

\begin{tabular}{|c|c|c|c|c|c|c|c|c|c|c|c|c|c|c|c|}
\hline Constructs & 1. & 2. & 3. & 4. & 5. & 6. & 7. & 8. & 9. & 10. & 11. & 12. & 13. & 14. & 15. \\
\hline 1. GN & 1.00 & & & & & & & & & & & & & & \\
\hline 2. DS & $0.53^{* *}$ & 1.00 & & & & & & & & & & & & & \\
\hline 3. RP & $0.53^{* *}$ & $0.39 * *$ & 1.00 & & & & & & & & & & & & \\
\hline 4. IN & $0.55^{\star \star}$ & $0.47^{* *}$ & $0.46^{* *}$ & 1.00 & & & & & & & & & & & \\
\hline 5. PT & $0.35^{* *}$ & $0.29^{* *}$ & $0.42^{* *}$ & $0.52^{* *}$ & 1.00 & & & & & & & & & & \\
\hline 6. RK & $0.19^{* *}$ & -0.01 & $0.16^{*}$ & $0.45^{* *}$ & $0.41^{* *}$ & 1.00 & & & & & & & & & \\
\hline 7. AO & $0.29^{* *}$ & $0.27^{\star *}$ & $0.26^{* *}$ & $0.40^{* *}$ & $0.24^{\star *}$ & $0.19^{* *}$ & 1.00 & & & & & & & & \\
\hline 8. CA & $0.23^{* *}$ & -0.02 & $0.21^{* *}$ & $0.36^{* *}$ & $0.21^{* *}$ & $0.44^{* *}$ & $0.30^{* *}$ & 1.00 & & & & & & & \\
\hline 9. EMO & $0.71^{* *}$ & $0.58^{* *}$ & $0.67^{* *}$ & $0.80^{* *}$ & $0.64^{* *}$ & $0.54^{* *}$ & $0.57^{* *}$ & $0.55^{* *}$ & 1.00 & & & & & & \\
\hline 10. CO & $0.31^{* *}$ & 0.11 & $0.31^{* *}$ & $0.43^{* *}$ & $0.23^{* *}$ & $0.48^{* *}$ & 0.08 & $0.40^{* *}$ & $0.47^{* *}$ & 1.00 & & & & & \\
\hline 11. PF & $0.34^{* *}$ & $0.31^{* *}$ & $0.26^{* *}$ & $0.49^{* *}$ & $0.37^{* *}$ & $0.38^{* *}$ & $0.13^{\dagger}$ & 0.08 & $0.45^{* *}$ & $0.24^{* *}$ & 1.00 & & & & \\
\hline 12. SZ & 0.10 & -0.07 & 0.03 & $0.16^{*}$ & -0.01 & $0.26^{* *}$ & -0.06 & $0.26^{* *}$ & $0.13^{\dagger}$ & $0.26^{* *}$ & $0.16^{*}$ & 1.00 & & & \\
\hline 13. AGE & -0.07 & -0.07 & 0.02 & -0.05 & -0.07 & 0.03 & -0.10 & 0.08 & -0.02 & $0.12^{\dagger}$ & $0.20^{* *}$ & $0.36^{* *}$ & 1.00 & & \\
\hline 14. IT & 0.09 & 0.04 & 0.00 & $0.18^{*}$ & 0.10 & $0.14 \dagger$ & 0.02 & $0.19^{* *}$ & $0.14 \dagger^{\dagger}$ & 0.10 & $0.22^{* *}$ & $0.23^{* *}$ & $0.21^{* *}$ & 1.00 & \\
\hline 15. EN & 0.08 & $0.16^{*}$ & 0.00 & -0.04 & -0.05 & $0.19^{* *}$ & 0.03 & -0.03 & -0.01 & $-0.21^{* *}$ & 0.06 & -0.06 & $0.35^{* *}$ & 0.08 & 1.00 \\
\hline
\end{tabular}


Table 5. Structural model

\begin{tabular}{|l|c|c|}
\hline Constructs & $\mathbf{V}$ & $\boldsymbol{t}$-values \\
\hline Firm size & -0.02 & -0.23 \\
\hline Firm age & 0.29 & 3.65 \\
\hline Degree of internationalisation & 0.03 & 0.68 \\
\hline Intelligence generation & 0.11 & 0.50 \\
\hline Intelligence dissemination & 0.07 & 0.38 \\
\hline Intelligence responsiveness & -0.09 & -0.64 \\
\hline Innovativeness & 0.35 & 2.45 \\
\hline Proactiveness & 0.02 & 0.19 \\
\hline Risk-taking & 0.19 & 2.43 \\
\hline Autonomy & -0.12 & -1.23 \\
\hline Competitive aggressiveness & -0.13 & -2.05 \\
\hline Entrepreneurial marketing orientation & -0.39 & -1.83 \\
\hline Coopetition & -0.08 & -0.97 \\
\hline Entrepreneurial marketing orientation $x$ coopetition & 0.09 & 1.68 \\
\hline Note: The critical $t$-value was 1.65 (5\%, one-sided, as the paths were directional). \\
\hline
\end{tabular}

